\title{
The Origin of University Teacher Development Center and the Construction of the Target
}

\author{
Zhou Zheng \\ Faculty development center, Shenyang University of Aeronautics and Astronautics, Shenyang 110136 \\ E-mail:65294906@qq.com
}

\begin{abstract}
- in this paper, starting from the foreign research materials, combing the domestic university center for teacher development origin and development process, aiming at the university teacher development center two organizing mode of teacher development center job prospects analysis and put forward reasonable center construction plan and mode to peer induced resonance.
\end{abstract}

Keywords-teacher development; teacher development center in Chinese universities

\section{INTRODUCTION}

Clark Kerr in the interpretation of the function of the University said, from teaching, research, social services to cultural heritage innovation, the evolution of the history of the university functions from the village to the diversified city". The change of higher education in China is from special education to general education, teachers from the center to the center for students' education. Therefore, the development of teachers is a lifeline, is the key point of the quality of personnel training (college students' comprehensive quality and innovation ability), and is the core of the development of higher education reform, the most urgent task.

\section{TEACHER DEVELOPMENT AND TEACHER DEVELOPMENT CENTER}

Broadly speaking, teacher development is through different ways and a variety of ways to improve the teachers' teaching and the ability, from the narrow sense, we can understand for teacher development needs through the specialized organization, from the service for teachers, helping, consultation and evaluation means to improve the ability of the teachers. Our study based on three perspectives: one is (the quality of the education popularity, young teachers, students level of diversification) development of higher education, educational philosophy, teaching ideas, teaching methods reform need professional training; the second is the teacher individual development of professional guidance (University Teachers' professional development survey, art of teaching and teaching to enhance the ability of and so on); the third is the academic teaching needs strict training, teaching and learning academic and teaching ability in need of training.

So far, USNEWS University in the United States ranked top 30 schools all set up specialized teacher development and training institutions; in the UK has now been widely established center of teacher development in Colleges and universities, but also to establish a perfect multi level teacher training and development system; in Japan. In recent years, in 713 Institute survey of the University in the establishment of university faculty development accounted for $80 \%$. We can infer, with the development of the popularization of higher education and higher education teaching quality of pressing to increase, Faculty Development Center this set up a specialized agency is the inevitable trend of the development, in line with the characteristics of the times and reality.

In July 2012, the Ministry of education started teaching demonstration center construction work and issued "on the launch of the National Teachers' teaching demonstration center construction work notice" (teach our letter [2012]107,), the following referred to as the "notice" [the Ministry of education. University of national teacher teaching demonstration center construction work notice on startup, and intends to "Twelfth Five Year Plan" period in the central ministries and the key support 30 national teacher teaching demonstration center, since domestic colleges and universities gradually understanding and began to build in line with the characteristics of the university teacher development center. Four aspects, the development of teacher development including the teachers' professional development, teaching ability development, career planning and development and personal qualities. Therefore, faculty development center should be positioned as "teaching for teachers, teaching managers support services", school for teachers in teaching and personal growth talent, academic upgrading and career development provide professional guidance and organization guarantee of individual institutions. We will be positioned as a teacher development center to achieve training research services, expand the functions of the assessment of the basic functions of the assessment, etc..

\section{THE ORIGIN OF THE DOMESTIC UNIVERSITY TEACHER DEVELOPMENT CENTER}

Since the $21 \mathrm{st}$ century, with the attention and recognition of higher education, University Teachers Training in our country walked slowly on institutionalized, the scale of the road, from the Ministry of education from top to bottom layer by layer multistage teacher training system is established, in spite of this, then University Faculty only stop in teacher training "want me to learn" stage. With 
the opening of the 12th Five year plan completed and 45 planning, model transformation of college education and teaching reform into the task faced by university teachers, teachers to continue learning, business ability to improve and the construction of teachers' team these realistic problems emerge universities gradually to attention to the concept of "teacher development". Pan Maoyuan, teacher development is based on from the teacher's subjectivity, self required to achieve a certain goal, of course, teacher development can not be separated from some form of education, training, but pay more attention to the is teachers' autonomy and personalized, promote teachers' self-regulated learning and self - improvement [pan Mao yuan 2007], from the focus on the "training" to focus on the "development" reflects the change of the concept of China's higher education. However, compared with foreign countries, our country to set up the center of teacher development started late, especially in recent years, the local colleges and universities to have established, current domestic teachers hair exhibition center building mode is mainly the following two:

First, the non entity institutions, institutions without full-time staff, all activities are designed and arranged by the teacher volunteers, funded by the school, the center of the activities carried out by the administrative intervention. The formation mode of the drawbacks obviously, only from teachers spontaneous organizations and individuals interested in angle to carry out activities, a lot of work without fixed arrangement and system security, unable to realize the sustainable development of teacher development center.

Second, entity organization, have full-time staff specialized in management or research work, although the center of colleges and Universities under the Department are different, but the center is entity organization, more adequate full-time staff, which is the purpose of the establishment of institutions and agencies to fulfill the mission to provide the guarantee of organization and personnel, is conducive to the development of school teachers teaching system, institutionalization and normalization, to expand the benefit side of teacher group, the center for teaching and learning development, bigger and stronger.

\section{THE DEVELOPMENT PROSPECTS OF THE DOMESTIC UNIVERSITY TEACHER DEVELOPMENT CENTER AND WORK OBJECTIVES}

With the planning of the completion of the "Twelfth Five Year Plan" and "45", our country University Center for teacher development in groping to move on, in the transformation of higher education, the role of Teacher Development Center will become increasingly prominent. The future, the center will focus on young teachers and teachers of basic courses in business level and improve the teaching ability as the focus, to further improve the teachers' development mechanism, normalization and institutionalization, to promote the work of the professional teachers teaching development, improving teachers' teaching ability and level, strive to develop a high level of professionalism and business strong ability and innovative spirit of the development of teaching staff, the construction of a series of excellent quality, good use effect, high utilization of digital curriculum resources, and find out a combination of the characteristics of the school, the teachers' teaching ability. The path of ascension, help to cultivate a group of outstanding teaching team, teaching and teacher teaching achievements, create a cultural atmosphere of teaching, teaching research, teaching in the teaching of college and painstaking efforts to move forward. University Teachers Development Center of the specific work should focus on the realization of the professional academic development of teachers, career planning, development of teaching ability and personal quality development of the four objectives of the work carried out:

\section{A. Training Teachers' Professional Academic Development Ability}

University teachers should and must be active in the forefront of academic research, and academic growth has a long way to go. The primary goal is the development of teachers training professional teachers' academic development ability, therefore, around this goal, to achieve the following four functions: one is the center for the development of teachers can help young teachers to build team join the academic mainstream opportunities, get the support and guidance of senior experts, relying on the academic platform to accelerate the development of the overall planning is two; and for the young teachers have access to schools and external financial support to participate in academic conferences, study at home and abroad to visit learning opportunities; the three is to guide teachers to learn to use academic exchange platform, academic journals and international conferences for consultation, exchange with counterparts at home and abroad; four is the reserve of the high school advanced talents, construction of high level the talent of the research team, to create a strong academic atmosphere of scientific research development, the formation of peer development scientific research echelon, set the backbone and conquer cutting-edge academic team Question.

\section{B. Promote the Development of Teachers' Teaching Ability}

Teachers in Colleges and universities the main work is imparting knowledge and the improvement of teaching ability is centralized embodiment of the teacher's professional standards and the ability to work. In view of some confusion, lack of practical experience and training of young teachers teaching the students face characteristics and individual differences in the new period of teaching object and the objective conditions of current Internet plus, a center for faculty development is to help young teachers to become excellent teachers, for the introduction of new teachers teaching teachers designated as a mentor, to achieve the school, school system a guide to the rapid growth of young teachers for teaching experts; the two is the creation of 
teaching reform, teaching method, teaching practice platform, such as relying on sharing and communication according to the students' individual differences and learning problems in the process of updating the teaching mode and teaching means innovation WeChat public platform of Teacher Development Center, teaching organization the contest, expert lectures and other activities to enhance the enthusiasm of teachers and teaching innovation; the three is to encourage and support teachers. The use of a variety of teaching methods, such as presentation tools, network, classroom communication systems and online courses, and other new technologies to enhance classroom fun, optimize the teaching content.

\section{Guidance Teachers Career Planning Development Path}

University teachers are responsible for personnel training, scientific research and social services three tasks, usually think the university teacher teaching, work and stable income, rarely think about occupation planning issues, according to this, the development of university teachers must change the traditional mode, has the heart of teachers' development responsibility to enhance teachers' awareness and understanding of occupation planning and provide some professional guidance, help teachers requirements university teachers practice summary into Teachers' self-awareness and self reflection -- making planning -theoretical study and occupation Reserve -- Practice and action research -- a summary of the promotion of university organizational learning from the past, through the teachers' occupation planning as soon as possible self positioning, a clear development of occupation he is teaching practice talents and scientific research talents, and strive for.

\section{To Provide a Platform for The Development of Personal Qualities of Teachers}

The personal quality of university teachers includes organization and coordination ability, environment adaptation ability, mental ease ability, innovation ability and consciousness level. Teacher development center can provide teachers with many aspects of the platform: one is to enhance the quality of personal activities and guidance center to meet the new teachers' sense of belonging to community development center; two teachers integrate school resources, adopt scientific policy more flexible allocation for young teachers in some scientific research projects and the corresponding resources to guarantee the development opportunities of new teachers have passion and courage enough and resources; three is the platform to expand teachers' disciplines, broaden scholarly exchange, especially interdisciplinary exchanges and cooperation to make the teachers of knowledge in different fields of contact and understanding will greatly enrich the teachers' creativity; four is the unity of thinking, to improve the understanding, the majority of teachers (inside and outside the party) will transfer the mainstream ideology, foreign advanced academic ideas into their subject characteristics, social service in China The construction of the socialist cause.

\section{REFERENCE}

[1] Li Wenying, Chen Jun, Nihon University, the institutionalization of teacher development [J] Journal of Baoding Institute of science and 2010, (1): 105).

[2] Pan Maoyuan. The development of university teachers and the improvement of the quality of Education [J] Journal of Shenzhen University (HUMANITIES AND SOCIAL SCIENCE EDITION) 2007, (1): 24.

[3] Notice of the Ministry of education on starting up the work of the construction of the National Teachers' teaching development demonstration center ([2012]107).

[4] Zhu Xudong. Study on the theory of teacher professional development [M] Beijing: Beijing Normal University press, 2011.

[5] Tubin. Fantasy Dorit, Vision, Metaphor -Three and Tracks to Teachers Minds [J] Qualitative The, September, 2005, 10 Report (3): 543-560. 